\title{
THE EFFECTS OF ADRENAL STEROIDS AND POTASSIUM DEPLETION ON THE ELABORATION OF AN OSMOTICALLY CONCENTRATED URINE *
}

\author{
By GERHARD GIEBISCH † AND RODOLFO LOZANO $\ddagger$ WITH THE TECH NICAL ASSISTANCE \\ oF ANITA MACEO
}

(From the Department of Physiology, Cornell University Medical College, New York, N. Y.)

(Submitted for publication August 19, 1958; accepted January 29, 1959)

The investigation reported in this paper is concerned with the effects of desoxycorticosterone acetate (DCA), hydrocortisone and dietary potassium depletion on the elaboration of an osmotically concentrated urine in the hydropenic state. Loeb and his associates $(1,2)$ demonstrated that dogs maintained on large amounts of DCA develop a diabetes insipidus-like picture. Since then, renal function studies in man (3-5), dogs (6) and rats $(7,8)$ have shown that the ability of the kidney to concentrate the urine is markedly reduced in states of adrenal hyperfunction and potassium deficiency. The mechanism by which polyuria is produced under these conditions has not been established. In particular, the role of potassium deficiency is still a matter of controversy. Thus, contrary to Loeb and co-workers $(1,2)$, who were unable to prevent the development of polyuria in their DCA-treated animals by feeding potassium chloride, some authors maintain (9) that the increased loss of potassium following the administration of adrenal steroids is responsible for the impairment of water conservation. Also, there is no agreement on the sensitivity of the kidney to vasopressin (Pitressin ${ }^{\circledR}$ ) during various states of potassium depletion $(7,9)$.

The present study is an attempt to clarify some of these points. We have, in particular, studied the formation of a concentrated urine during osmotic diuresis in the hydropenic state. According to current concepts, an osmotically concentrated urine can be visualized as being made up of an isosmotic portion less the amount of water abstracted from it to produce hypertonicity $(10,11)$.

\footnotetext{
* Aided by a grant from the National Heart Institute, Bethesda, Md.

$\dagger$ This work was done during the tenure of an Established Investigatorship of the American Heart Association.

$\ddagger$ Fellow of the Rockefeller Foundation. Present address: Instituto de Biologia Andina, Apartado 1116, Lima, Peru.
}

This latter moiety has been designated $\mathrm{T}^{\mathrm{c}}{ }_{\mathrm{H}_{2} \mathrm{O}}(10$, 11 ) or water economy (12) and direct evidence indicates that the collecting duct system is the site where the process of final water abstraction occurs $(13,14)$. Contrary to findings obtained on control animals in which variations of $\mathrm{T}^{\mathrm{c}} \mathrm{H}_{2} \mathrm{O}$ are fairly small over a wide range of urine flows, our results show that DCA administration produces a significant and progressive reduction of that amount of water as urine flow increases. Also, at higher flow rates the occurrence of marked hypotonicity was a frequent finding, thus indicating that the fluid reaching the site of final water abstraction was not rendered isosmotic during its passage along the distal tubule and collecting duct $(13,14)$.

\section{METHODS}

Thirty-eight experiments were performed on nine female mongrel dogs ranging in weight from 17 to $25 \mathrm{Kg} .{ }^{1}$ Anesthesia was induced and maintained by appropriate amounts of sodium pentobarbital given intravenously. In all animals data on osmolality of urine and plasma at low urine flow rates and during osmotic diuresis were obtained before and after treatment with various hormones and diets. Thus, each animal served as its own control. Since, in particular, variations in the protein intake have been shown to influence the concentrating ability of the kidney (15), a diet of constant composition was supplied to all animals during each sequence of experiments. Usually this diet was a mixture of horse meat and meal having a similar composition to that used in a previous investigation (16). Additional sodium chloride in amounts varying between 86 and $172 \mathrm{mEq}$. per day was given during treatment with DCA and hydrocortisone (16-18). Dietary potassium depletion was induced by feeding a synthetic diet having the same composition as that used in a previous investigation (16).

Desoxycorticosterone acetate (DCA) in sesame oil (Cortate ${ }^{\circledR}$, Schering) was given intramuscularly in a dose of $1.0 \mathrm{mg}$. per $\mathrm{Kg}$. per day for periods lasting 6 to

$1 \mathrm{We}$ are indebted to Mr. L. Glasser and Mr. F. J. Erdman, Jr., who carried out eight experiments under our supervision in the course of second year project teaching in physiology. 
TABLE I

Results of a typical experiment showing effect of mannitol diuresis on elaboration of a concentrated urine in the hydropenic state (Experiment 12, $23 \mathrm{Kg}$. dog)*

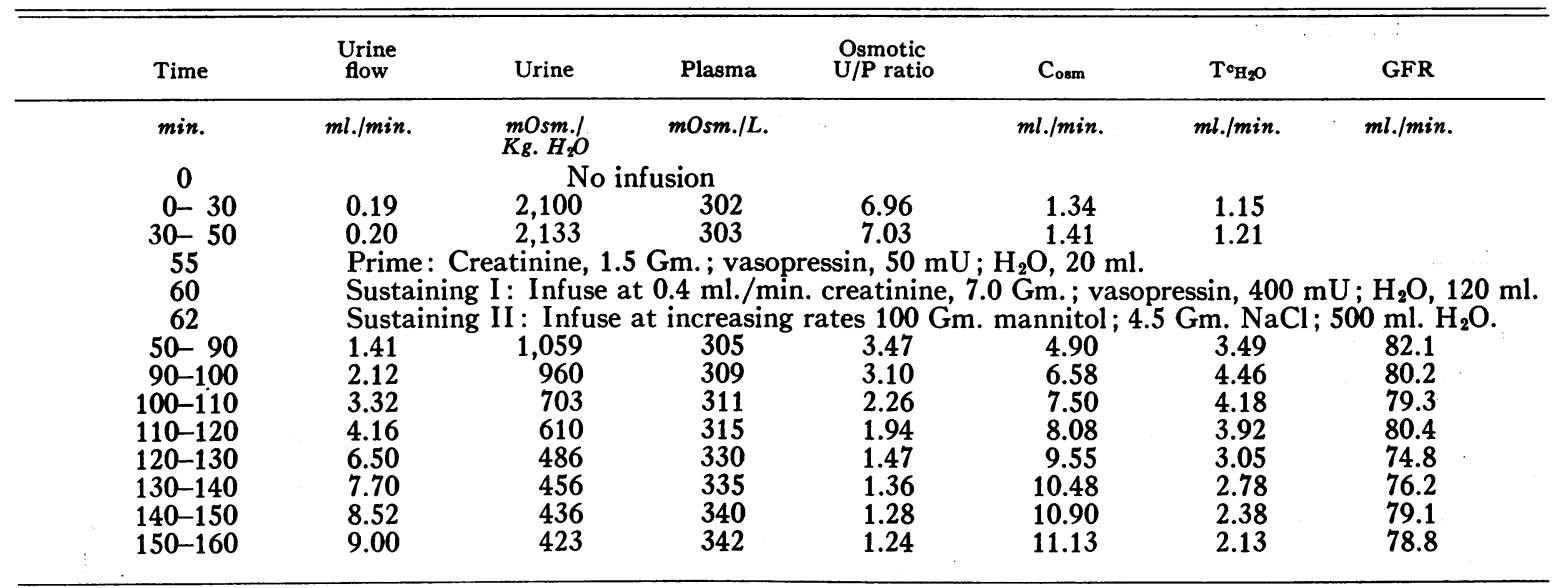

* Preinfusion plasma potassium level : $3.80 \mathrm{mEq}$. per L.

24 days. Hydrocortisone (Cortef ${ }^{\circledR}$, Schering) was administered intramuscularly in doses of 7.5 and $10 \mathrm{mg}$. per $\mathrm{Kg}$. per day for periods of 6 to 13 days. On the day of the experiment, 100 to $150 \mathrm{mg}$. were included in the priming and sustaining infusion.

Prior to all experiments the animals were rendered hydropenic by deprivation of water for 48 hours and withholding of food for 24 hours. After such preparation minimal rates of urine flow were observed, and one to three urine samples were collected over a period of from 30 to 90 minutes. Subsequently, osmotic diuresis was induced by intravenous administration of a 20 per cent mannitol solution given at a rate varying between 1 and $9 \mathrm{ml}$. per minute. This infusion contained a small amount of sodium chloride ( $4.5 \mathrm{Gm}$. per L.) to avoid marked changes in the plasma sodium concentration (19). Simultaneously, a second infusion was given at a rate of $0.4 \mathrm{ml}$. per minute to maintain the plasma level of creatinine and vasopressin (Pitressin@, Parke, Davis and Co.) at a constant level. An appropriate priming infusion containing creatinine and vasopressin ( 40 to $340 \mathrm{mU}$ ) preceded this second infusion. An equilibration period of 20 to $65 \mathrm{~min}$ utes was allowed after the start of these two separate sustaining infusions before urine samples were collected. Almost all observations during mannitol infusions were made during increasing osmotic diuresis. Urine was collected by means of an indwelling catheter, residual urine being expelled by air. No washout fluid was used. Blood samples were drawn into heparinized syringes at the midpoint of each collection period either from the femoral artery or the jugular vein.

Plasma and urine samples were analyzed for creatinine (20), the clearance of which was used as a measure of glomerular filtration rate. Urine and plasma osmolality were determined cryoscopically using a Fiske osmometer. Analyses for potassium were done on preinfusion plasma samples by methods previously described (16). Glucose $T_{m}$ and glucose titrations were performed on two ani- mals prior to and following DCA administration. The methods used in these experiments were essentially those described in a recent publication from this laboratory (21).

\section{RESULTS}

\section{Relationship between urine flow and urine os- molality in control and DCA-treated animals}

The effects of varying degrees of mannitol diuresis on the relationship between urine flow and urine osmolality during a typical control experiment are shown in Table I. During the two preinfusion collections, the urine flow was at low levels of about $0.2 \mathrm{ml}$. per minute. Concomitantly, urine osmolality exceeded that of plasma about sevenfold as indicated by the respective osmotic $\mathrm{U} / \mathrm{P}$ ratios. Both the osmolal clearance $\left(\mathrm{C}_{\mathrm{osm}}\right)$ and the amount of solute-free water reabsorbed $\left(\mathrm{T}^{\mathrm{c}}{ }_{\mathrm{H}_{2} \mathrm{O}}\right)$ have small absolute values. ${ }^{2}$ Urine flow

2. Hypertonic urine is envisaged as consisting of two hypothetical portions: 1) an isosmotic moiety (osmolal clearance, $C_{o s m}$, equalling $U_{o s m} V / P_{o s m}$ ) and 2) that amount of solute-free water which has to be abstracted from it to produce the observed hypertonicity. This amount is referred to as $\mathrm{T}^{\mathrm{c}} \mathrm{H}_{2} \mathrm{O}$ and numerically equals $\mathrm{C}_{\mathrm{osm}}-\mathrm{V}$. On the other hand, a hypotonic urine can be represented by an isosmotic portion $\left(\mathrm{C}_{\mathrm{osm}}\right)$ and that additional amount of solute-free water which would have to be added to reduce its osmotic concentration to that observed. This latter moiety equals $\mathrm{V}-\mathrm{C}_{\mathrm{s} s \mathrm{~m}}$ and is referred to as $\mathrm{C}_{\mathrm{H}_{2} \mathrm{O}}$. This concept as presented is that of Wesson and Anslow (10), but certain important considerations as to its application should be noted (22). 
increased markedly after the 20 per cent mannitol solution was infused at increasing rates. In this experiment the peak urine flow reached $9.0 \mathrm{ml}$. per minute. As the urine flow increased, urine osmolality fell progressively but at all times remained distinctly above that of plasma as can be seen from the respective osmotic $U / P$ ratios which exceeded unity at all urine flows. It is evident that $\mathrm{T}^{\mathrm{c}} \mathrm{H}_{2} \mathrm{O}$ at first increased and then levelled off when urine flow rates exceeded about $2 \mathrm{ml}$. per minute. No significant changes in glomerular filtration rate were observed during the infusion of mannitol in this and other control experiments. The observed relationship between urine flow, osmolal clearance and $\mathrm{T}_{\mathrm{H}_{2} \mathrm{O}}^{\mathrm{O}}$ is in essential agreement with findings reported by Page and Reem (19) and others $(11,22)$. It should be noted that similar results were obtained when higher doses of vasopressin ( 80 to $340 \mathrm{mU}$ priming, 80 to $500 \mathrm{mU}$ per hour sustaining infusion) were given. Furthermore, we never observed an increase in $\mathrm{T}^{\mathrm{e}} \mathrm{H}_{2} \mathrm{O}$ when the level of vasopressin was acutely increased by supplements of 100 and $200 \mathrm{mU}$ vasopressin administered intravenously. This also is in agreement with Zak, Brun and Smith (11) indicating that hydropenia and hypertonic mannitol infusions produce maximal effects on the elaboration of an osmotically concentrated urine which cannot be enhanced by increasing the amounts of exogenous vasopressin.

The relationship between urine flow and urine osmolality was strikingly different after DCA treatment. A representative experiment is presented in Table II. Treatment with this steroid and the administration of a sodium chloride supplement resulted in a reduction of the preinfusion plasma potassium level to a subnormal value (2.5 mEq. per L). Urine osmolality at low urine flows was significantly reduced as can be seen from the low osmotic U/P ratios of 2.29 and 2.27, respectively. As urine flow increased, urine osmolality fell, and at flow rates of $4.4 \mathrm{ml}$. per minute and above, the urine formed became hypotonic (osmotic $\mathrm{U} / \mathrm{P}$ ratios below 1.0). It is also apparent that the values of $\mathrm{T}^{\mathrm{c}} \mathrm{H}_{2} \mathrm{O}$ decreased steadily as the urine flow increased. Despite the continuing administration of vasopressin, higher rates of mannitol diuresis enhanced urinary hypotonicity leading to a progressive rise of $\mathrm{C}_{\mathrm{H}_{2} \mathrm{O}}$ from values of $0.26 \mathrm{ml}$. per minute to $2.60 \mathrm{ml}$. per minute at peak urine flows. Inspection of the last column shows that glomerular filtration rates remained fairly constant throughout the course of the experiment.

Figure 1 contains results of a typical sequence of three experiments (Experiments 14, 21 and 24, performed on Dog No. 1, see Tables III and IV) showing the effects of DCA treatment and potassium repletion. Data of the respective control experiment are included. Urine flow is plotted on the abscissa and osmolal clearance $\left(\mathrm{C}_{\text {osm }}\right)$ on the ordinate. Solute-free water clearance $\left(\mathrm{C}_{\mathrm{H}_{2} \mathrm{O}}\right)$ is given by the horizontal distance between the diagonal line (isosmotic parameter) and the observed points to the right. The amount of solute-free

TABLE II

Results of an experiment showing the effect of $D C A(1.0 \mathrm{mg}$. per $\mathrm{Kg}$. per day for six days) on the elaboration of a concentrated urine in the hydropenic state (Experiment $20,23 \mathrm{Kg}$. dog) *

\begin{tabular}{|c|c|c|c|c|c|c|c|c|}
\hline Time & $\begin{array}{l}\text { Urine } \\
\text { flow }\end{array}$ & Urine & Plasma & $\begin{array}{l}\text { Osmotic } \\
\text { U/P ratio }\end{array}$ & $\mathrm{C}_{\text {osm }}$ & $\mathrm{T}^{\mathrm{c}} \mathrm{H}_{2} \mathrm{O}$ & $\mathrm{C}_{\mathrm{H}_{2} \mathrm{O}}$ & GFR \\
\hline $\min$ & ml./min. & $\underset{\mathrm{Kg} . \mathrm{H} \cdot \mathrm{O}}{\mathrm{mOsm}}$ & \multicolumn{2}{|l|}{$m O s m . / L$} & ml./min. & ml./min. & ml./min. & ml./min. \\
\hline 0 & \multicolumn{8}{|c|}{ No infusion } \\
\hline $0-30$ & 0.11 & 687 & 300 & 2.29 & 0.25 & 0.14 & & \\
\hline $30-50$ & 0.10 & 684 & 302 & 2.27 & 0.25 & $\begin{array}{l}0.14 \\
0.15\end{array}$ & & \\
\hline 55 & \multicolumn{8}{|c|}{ Prime: Creatinine, $1.5 \mathrm{Gm}$.; vasopressin, $50 \mathrm{mU} ; \mathrm{H}_{2} \mathrm{O}, 20 \mathrm{ml}$. } \\
\hline 60 & \multirow{2}{*}{\multicolumn{8}{|c|}{$\begin{array}{l}\text { Sustaining I: Infuse at } 0.4 \mathrm{ml} . / \mathrm{min} \text {. creatinine, } 7.0 \mathrm{Gm} \text {. vasopressin, } 400 \mathrm{mU} ; \mathrm{H}_{2} \mathrm{O}, 120 \mathrm{ml} \\
\text { Sustaining II : Infuse at increasing rates } 100 \mathrm{Gm} \text {. mannitol; } 4.5 \mathrm{Gm} \text {. NaCl; } 500 \mathrm{ml} . \mathrm{H}_{2} \mathrm{O}\end{array}$}} \\
\hline 62 & & & & & & & & \\
\hline $50-90$ & 0.94 & 496 & 306 & 1.62 & 1.53 & 0.59 & & \\
\hline $90-100$ & 1.32 & 408 & 307 & 1.33 & 1.76 & 0.44 & & 69.3 \\
\hline $100-110$ & 1.92 & 365 & 310 & 1.18 & 2.26 & 0.34 & & 67.0 \\
\hline $110-120$ & 4.40 & 293 & 313 & 0.94 & 4.14 & & 0.26 & 74.0 \\
\hline $120-130$ & 5.90 & 278 & 318 & 0.87 & 5.16 & & 0.74 & 69.3 \\
\hline $130-140$ & 8.70 & 257 & 326 & 0.79 & 6.87 & & 1.83 & 66.5 \\
\hline $140-150$ & 11.50 & 257 & 332 & 0.77 & 8.90 & & 2.60 & 66.5 \\
\hline
\end{tabular}

* Preinfusion plasma potassium level : $2.50 \mathrm{mEq}$. per L. 
TABLE III

Osmotic diuresis during hydropenia and vasopressin administration in control and potassium repleted dogs

\begin{tabular}{|c|c|c|c|c|c|c|c|c|c|c|c|c|}
\hline \multirow[b]{2}{*}{ Condition } & \multirow[b]{2}{*}{ Dog } & \multirow[b]{2}{*}{ Expt. } & \multirow{2}{*}{$\begin{array}{c}4 \\
\text { Urine } \\
\text { flow } \\
\text { (range) }\end{array}$} & \multirow{2}{*}{$\begin{array}{c}5 \\
\text { Max. } \\
\text { osmotic } \\
\text { U/P ratio }\end{array}$} & \multirow{2}{*}{$\begin{array}{c}6 \\
\text { Max. } \\
\mathrm{T}^{\circ} \mathrm{H}_{2} \mathrm{O}^{*}\end{array}$} & \multirow{2}{*}{$\begin{array}{c}7 \\
\text { Regression } \\
\text { coeff.† } \\
\text { (slope) }\end{array}$} & \multirow{2}{*}{$\begin{array}{c}8 \\
\text { Correl. } \\
\text { coeff.f }\end{array}$} & \multirow{2}{*}{$\begin{array}{c}9 \\
\underset{\text { (range) }}{\text { Posm }}\end{array}$} & \multirow{2}{*}{$\begin{array}{c}10 \\
\underset{\mathrm{K} \delta}{\text { Plasma }}\end{array}$} & \multirow{2}{*}{$\begin{array}{c}11 \\
\underset{\text { (mean) }}{\text { GFR }}\end{array}$} & \multicolumn{2}{|c|}{${\stackrel{12}{\text { Pitressin }}{ }^{13}}^{13}$} \\
\hline & & & & & & & & & & & Prime & $\begin{array}{c}\text { Sus- } \\
\text { tainin }\end{array}$ \\
\hline & no. & no. & ml./min. & & ml./min. & & & $\begin{array}{l}\mathrm{mOsm} . \mathrm{I} \\
\mathrm{Kg} . \mathrm{H} \mathrm{O}\end{array}$ & $m E q . / L$ & ml./min. & $m U$ & $m U / h r$ \\
\hline $\begin{array}{l}\text { Control } \\
\text { Control } \\
\text { Control } \\
\text { Control } \\
\text { Control } \\
\text { Control } \\
\text { Control } \\
\text { Control } \\
\text { Control } \\
\text { Control } \\
\text { Control }\end{array}$ & $\begin{array}{l}1 \\
2 \\
3 \\
4 \\
1 \\
5 \\
6 \\
7 \\
4 \\
8 \\
9\end{array}$ & $\begin{array}{r}2 \\
6 \\
11 \\
12 \\
14 \\
23 \\
31 \\
32 \\
13 \\
36 \\
39\end{array}$ & $\begin{array}{l}0.13-11.0 \\
0.12-7.0 \\
0.19-5.5 \\
0.19-9.0 \\
0.09-9.4 \\
0.15-10.4 \\
0.09-9.5 \\
0.10-6.0 \\
0.05-7.5 \\
0.08-12.6 \\
0.10-8.8\end{array}$ & $\begin{array}{l}4.83 \\
5.24 \\
4.94 \\
7.03 \\
5.28 \\
5.18 \\
6.63 \\
7.58 \\
4.45 \\
6.39 \\
5.71\end{array}$ & $\begin{array}{l}2.00 \\
1.97 \\
2.57 \\
4.46 \\
2.46 \\
2.10 \\
2.55 \\
2.31 \\
4.02 \\
3.40 \\
2.40\end{array}$ & $\begin{array}{l}0.993 \\
0.980 \\
1.050 \\
0.900 \\
0.968 \\
0.863 \\
0.870 \\
0.873 \\
1.360 \\
1.170 \\
0.910\end{array}$ & $\begin{array}{l}0.984 \\
0.977 \\
0.979 \\
0.999 \\
0.985 \\
0.999 \\
0.992 \\
0.999 \\
0.969 \\
0.991 \\
0.959\end{array}$ & $\begin{array}{l}293-311 \\
296-322 \\
281-298 \\
302-342 \\
304-330 \\
304-331 \\
299-332 \\
305-336 \\
301-324 \\
303-321 \\
287-302\end{array}$ & $\begin{array}{l}3.75 \\
3.90 \\
3.95 \\
3.80 \\
3.64 \\
3.75 \\
3.68 \\
3.41 \\
3.99 \\
3.91 \\
3.66\end{array}$ & $\begin{array}{l}81.3 \\
51.3 \\
82.9 \\
71.0 \\
59.0 \\
66.2 \\
74.0 \\
56.0 \\
85.0 \\
68.0 \\
70.7\end{array}$ & $\begin{array}{l}40 \\
40 \\
40 \\
40 \\
40 \\
40 \\
40 \\
40 \\
40 \\
20 \\
20\end{array}$ & $\begin{array}{l}80 \\
80 \\
80 \\
80 \\
80 \\
80 \\
80 \\
80 \\
80 \\
44 \\
44\end{array}$ \\
\hline $\begin{array}{l}\text { Mean value } \\
\text { Standard devi }\end{array}$ & viation & & & $\begin{array}{r}5.75 \\
\pm 1.01\end{array}$ & $\begin{array}{r}2.95 \\
\pm 0.86\end{array}$ & $\begin{array}{r}0.994 \\
\pm 0.152\end{array}$ & & & & & & \\
\hline $\begin{array}{l}\text { K-Repletion } \\
\text { K-Repletion } \\
\text { K-Repletion } \\
\text { K-Repletion } \\
\text { K-Repletion } \\
\text { K-Repletion }\end{array}$ & $\begin{array}{l}1 \\
4 \\
1 \\
4 \\
7 \\
7\end{array}$ & $\begin{array}{r}9 \\
22 \\
24 \\
25 \\
37 \\
43\end{array}$ & $\begin{array}{l}0.12-6.3 \\
0.10-10.2 \\
0.10-9.6 \\
0.08-9.1 \\
0.06-9.2 \\
0.14-11.3\end{array}$ & $\begin{array}{l}4.80 \\
3.99 \\
4.94 \\
4.00 \\
7.46 \\
7.20\end{array}$ & $\begin{array}{l}1.86 \\
2.16 \\
1.33 \\
2.04 \\
2.65 \\
3.10\end{array}$ & $\begin{array}{l}0.950 \\
0.968 \\
1.018 \\
0.941 \\
1.080 \\
0.960\end{array}$ & $\begin{array}{l}0.985 \\
0.987 \\
0.955 \\
0.989 \\
0.990 \\
0.969\end{array}$ & $\begin{array}{l}306-324 \\
302-322 \\
308-336 \\
306-324 \\
306-345 \\
295-347\end{array}$ & $\begin{array}{l}4.40 \\
3.62 \\
3.37 \\
3.69 \\
3.89 \\
3.49\end{array}$ & $\begin{array}{l}66.0 \\
91.6 \\
61.2 \\
89.7 \\
51.9 \\
52.3\end{array}$ & $\begin{array}{r}40 \\
40 \\
40 \\
40 \\
40 \\
340\end{array}$ & $\begin{array}{r}80 \\
80 \\
80 \\
80 \\
80 \\
500\end{array}$ \\
\hline $\begin{array}{l}\text { Mean value } \\
\text { Standard devi }\end{array}$ & viatior & & & $\begin{array}{r}5.25 \\
\pm 1.28\end{array}$ & $\begin{array}{r}2.19 \\
\pm 0.62\end{array}$ & $\begin{array}{r}0.986 \\
\pm 0.054\end{array}$ & & & & & & \\
\hline
\end{tabular}

* Since the slope of $\mathrm{C}_{o s m}$ on $\mathrm{V}$ (regression coefficient) varied among animals and often deviated significantly from 1.0 , we have chosen to compare maximum solute-free water reabsorption instead of selecting a value of $\mathrm{T}^{\circ} \mathrm{H}_{2} \mathrm{O}$ at any arbitrarily selected urine flow rate.

$\dagger$ Regression of $C_{o s m}$ on $V$ was calculated by the method of least squares taking such points at higher urine flow rates as showed linear regression of $\mathrm{C}_{\text {osm }}$ on $\mathrm{V}$, thus care being taken not to include points within the range of splay of the titration curve at intermediate urine flow rates (38).

$\ddagger$ As pointed out by Boyarsky and Smith (38), the calculation of the correlation coefficient for linear regression of $\mathrm{C}_{\text {om }}$ on $\mathrm{V}$ is best performed by using the linear equation $\mathrm{U}_{\mathrm{osm}} \mathrm{V} / \mathrm{P}_{\mathrm{osm}}=\mathrm{aV}+\mathrm{b}$, and dividing both sides by $\mathrm{V}$. Thus the two variables, $U_{o s m} / P_{o s m}$ and $1 / V$, are independent and, in contrast to the original linear regression of $C_{\text {osm }}\left(=U_{o s m} V /\right.$ $\mathrm{P}_{\mathrm{osm}}$ ) on $\mathrm{V}$, do not contain simultaneous and correlated errors by having one variable, $\mathrm{V}$, occur in both terms.

$\$$ Plasma potassium levels were measured before any infusions were given.

water reabsorbed $\left(\mathrm{T}^{\mathrm{c}}{ }_{\mathrm{H}_{2} \mathrm{O}}\right)$ from $\mathrm{C}_{\mathrm{osm}}$ is shown by the horizontal distance between the isosmotic parameter and the experimental points to the left.

The experiments presented in Figure 1 illustrate two significant features. First, in the control and repletion experiment the osmolal clearance always exceeds the urine flow. It can be seen that the relationship between these two variables is such that the data generate a linear regression having a slope of approximately 1.0. In striking contrast, the slope is significantly less than 1.0 after DCA treatment. Second, it is evident that after DCA treatment a hypertonic urine was elaborated only at low urine flows. At about $5.4 \mathrm{ml}$. per minute a transition from hyper- to hypotonicity occurred. Inspection of Figure 1 also shows that these observed changes (reduction in osmolal
$\mathrm{U} / \mathrm{P}$ ratios, decreased $\mathrm{T}_{\mathrm{H}_{2} \mathbf{O}}$, decrease in slope of $\mathrm{C}_{\text {osm }}$ on $\mathrm{V}$ ) were almost completely reversible after DCA had been discontinued and oral potassium chloride supplements had been given for seven days. Essentially the same results were obtained in six similar sequences of experiments.

Figure 2 shows the effect of varying the amount of vasopressin after DCA treatment (Experiments 32, 33 and 34, performed on Dog No. 7, see Tables III and IV). In this animal, the effect of steroid administration was less marked. However, reduction of maximum osmolal $\mathrm{U} / \mathrm{P}$ ratios at minimal urine flows and a decrease of $\mathrm{T}^{\mathrm{c}} \mathrm{H}_{2} \mathrm{O}$ was observed. Furthermore, a small decrease in steepness of the slope of $\mathrm{C}_{\text {osm }}$ on $\mathrm{V}$ was seen. Doubling the amount of vasopressin had no significant effect on the process of urinary concen- 


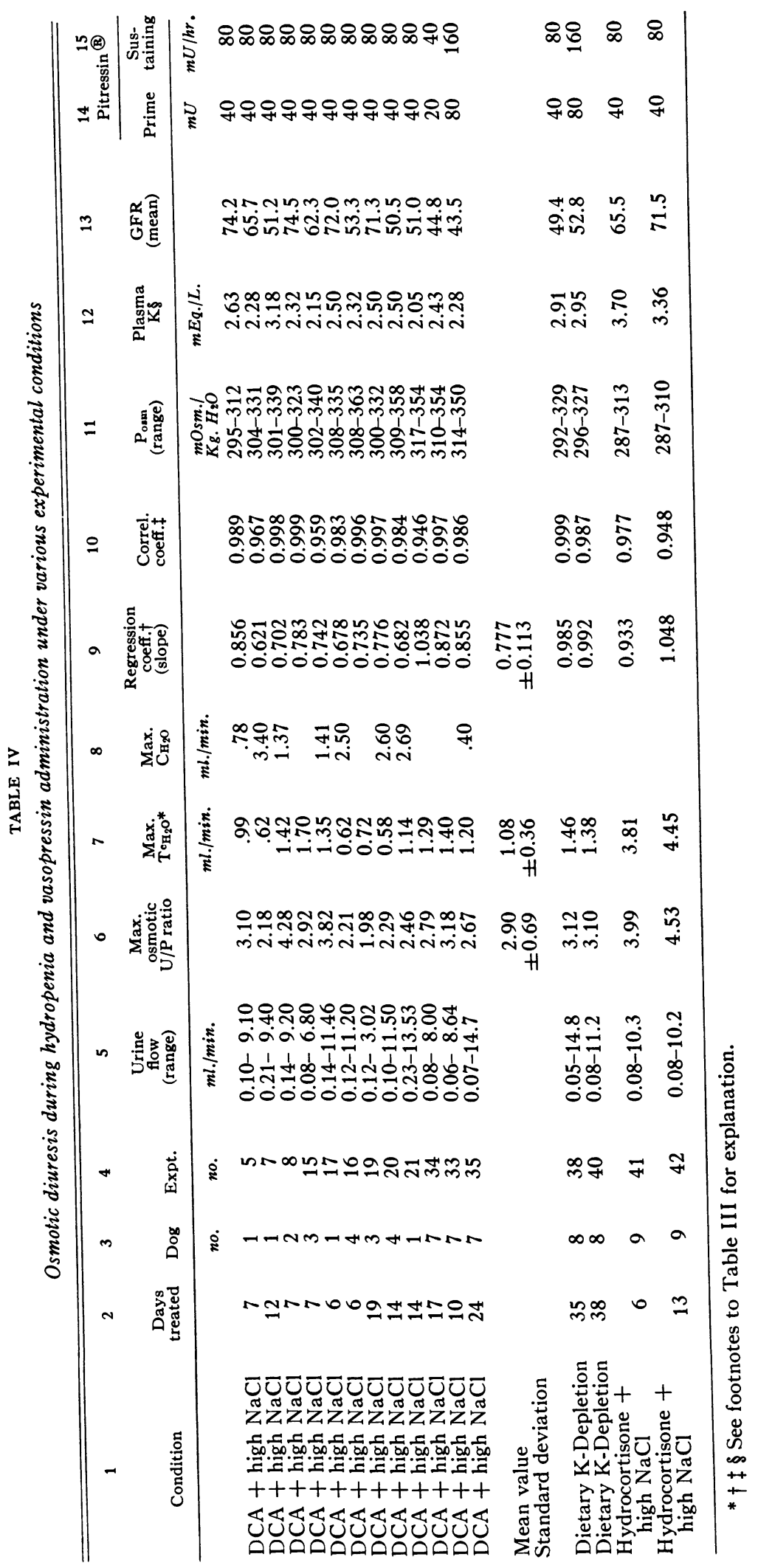




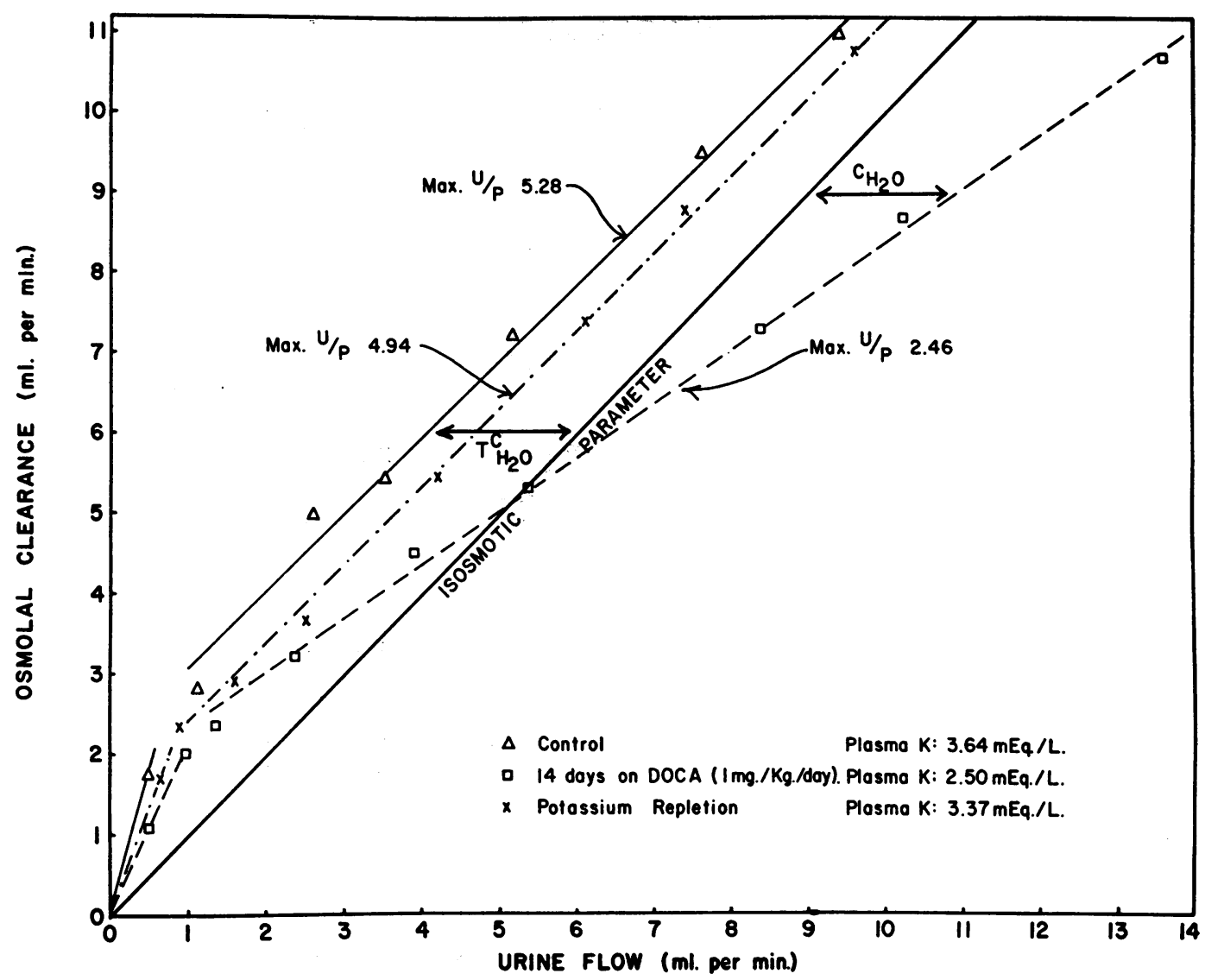

Fig. 1. The Relationship Between Urine Flow and Solute Excretion Under Control Conditions After DCA Treatment and Potassium Repletion

Maximum osmotic $\mathrm{U} / \mathrm{P}$ ratios were obtained at comparable low preinfusion urine flow rates.

tration. In an additional experiment, the dose of vasopressin was acutely increased in a stepwise fashion (priming infusion $80,160,320 \mathrm{mU}$ vasopressin, sustaining infusion $160,320,640 \mathrm{mU}$ vasopressin per hour). These additional amounts of vasopressin also were without effect on $\mathrm{T}^{\mathrm{c}} \mathrm{H}_{2} \mathrm{O}$ and the slope of $\mathrm{C}_{\text {osm }}$ on $\mathrm{V}$. This is in agreement with findings of other authors $(8,23)$ who observed that the polyuria developing after DCA treatment is vasopressin-resistant.

\section{Relationship between urine flow and urine os-} molality in animals on a high sodium chloride intake treated with hydrocortisone

In contrast to the results obtained with DCA, hydrocortisone in a dose of $7.5 \mathrm{mg}$. per $\mathrm{Kg}$. per day for six days and continued in a dose of 10.0 $\mathrm{mg}$. per $\mathrm{Kg}$. per day for another week did not, with the exception of a small reduction of osmolal $U / P$ ratios at low urine flows of questionable significance, result in a reduction of urinary concentrating ability. Plasma potassium levels were unchanged and filtration rate was unaltered after treatment with this steroid. Pertinent data are included in Tables III and IV.

\section{Relationship between urine flow and urine os- molality after dietary potassium depletion}

In one animal, a low potassium diet was given for a period of up to 38 days. Table III (Dog No. 8) and Table IV contain data on maximum osmolal U/P ratios, regression coefficients, plasma potassium levels and magnitude of glomerular filtration rate. A comparison of control values with data obtained after 35 and 38 days of feeding a low potassium diet shows that maximum osmotic $U / P$ ratios, $\mathrm{T}^{\mathrm{c}_{\mathrm{H}_{2} \mathrm{O}}}$ and plasma potassium levels were reduced following potassium deprivation. Doub- 


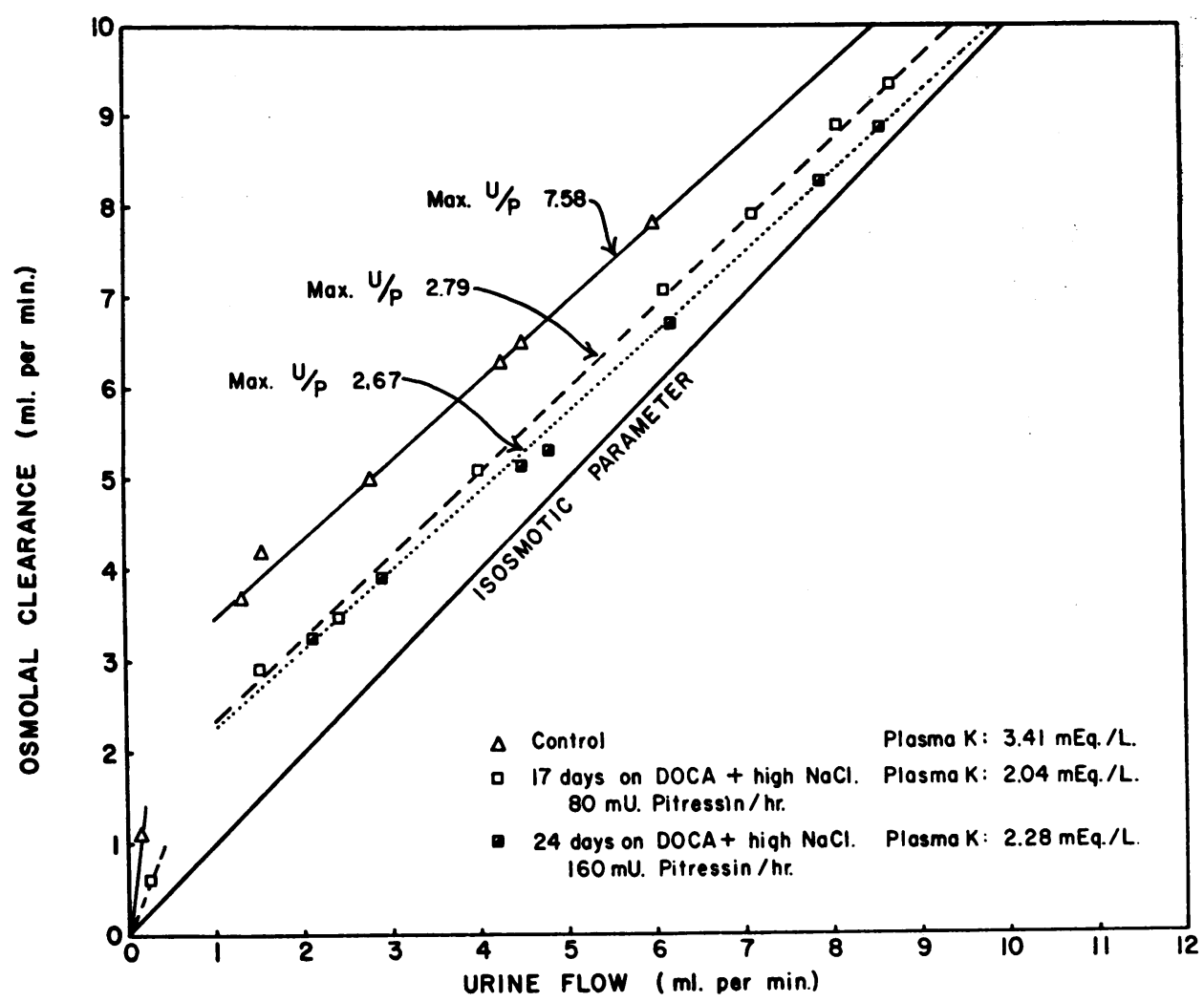

Fig. 2. The Relationship Between Urine flow and Solute Excretion Under Control Conditions and After DCA Treatment, Demonstrating No Significant Effect of Doubling the Amount of Vasopressin (Pitressin $\left.{ }^{(}\right)$Infused in This DCA-Treated Animal

ling the dose of vasopressin had no noticeable effects on the process of forming an osmotically concentrated urine. These results are in agreement with those of other authors $(4,8)$ who found that dietary potassium depletion results in a significant reduction of the urinary concentrating ability which is resistant to vasopressin.

Figure 3 presents a summary of the relationship between preinfusion plasma potassium levels and osmotic $\mathrm{U} / \mathrm{P}$ ratios at low urine flow rates during the several preinfusion control periods. In general, a reduced $U / P$ ratio is found in states accompanied by a low plasma potassium level. Hollander and associates (8) also observed that the renal concentrating ability is almost linearly related to the degree of potassium depletion measured by these authors by the fall in muscle potassium. In many conditions the plasma potassium level is a poor parameter of the degree of potassium depletion. However, in our experiments it appears to be safe to assume that the reduction of the plasma potassium concentration does reflect a state of potassium deficiency. Balance studies in various species are in accord with this assumption $(24,25)$. It is also obvious from inspection of Figure 4 that hydrocortisone was ineffective in lowering plasma potassium levels.

A summary of pertinent data of all experiments is tabulated in Tables III and IV, permitting a comparison of individual animals under control and various experimental conditions. While most of the data are self-explanatory, several points deserve consideration. Inspection of Column 7 in Table III shows that the variation of the slope of regression lines in control experiments is considerable, ranging from 0.87 to 1.36 . Inclusion of this latter value in the calculation of the mean (0.994) considerably biases this value, since in the majority of observations the slope relating urine flow to osmolal clearance deviates significantly from 1.0 , being lower in 8 out of 11 control experiments. In man, values closer to unity and having a smaller 


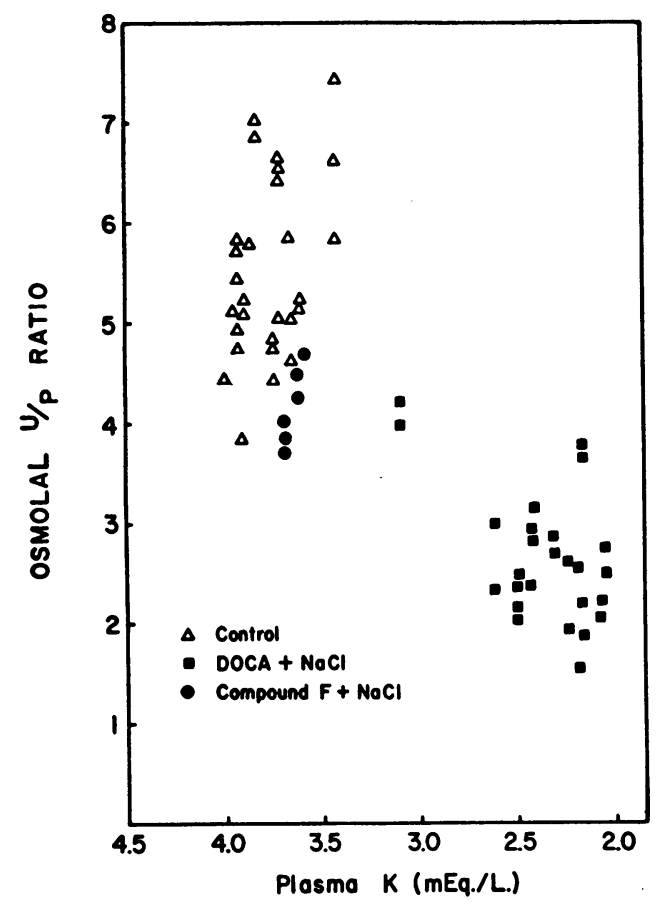

Fig. 3. The Relationship Between Osmolal U/P Ratios and Preinfusion Potassium Levels Under Various Experimental Conditions

Urine flow rates ranged from $0.06 \mathrm{ml}$. per minute to $0.17 \mathrm{ml}$. per minute.

standard deviation were observed by Zak, Brun and Smith (11). It is possible that the relatively larger increase of plasma osmolality observed in our experiments (Column 9, Table III) might explain slopes consistently lower than 1.0 since a sharp rise in plasma osmolality might not be reflected immediately in the urine osmolality and result in an erroneously low osmotic $\mathrm{U} / \mathrm{P}$ ratio (26). However, inspection of individual experimental protocols has not shown any clearcut relationship between rate of increase in plasma osmolality and regression coefficient. Comparison of data listed in Column 7 of Table III with those of Column 8 in Table IV indicates that in spite of similar variations in animals treated with DCA (on high $\mathrm{NaCl}$ intake), the regression coefficient is significantly lower in the latter, ranging from 0.621 to 1.03 , with a mean of 0.777 . Also, lower maximum osmotic U/P ratios (compare Column 5 in Table III with Column 6 in Table IV) and lower values of maximum $\mathrm{T}_{\mathrm{H}_{2} \mathrm{O}}$ (compare Column 6 in Table III with Column 7 in Table IV) are typical for DCA-treated animals on a high sodium chloride intake. Little significance should be attached to the absolute values of maximum $\mathrm{C}_{\mathrm{H}_{2} \mathrm{O}}$ (Column 8 , Table IV) other than indicating a significant degree of hypotonicity absent in untreated control animals over the same range of urine flows. ${ }^{3}$ Since most of the regression coefficients (Column 9, Table IV) are smaller than 1.0, the absolute value of $\mathrm{C}_{\mathrm{H}_{2} \mathrm{O}}$ obviously depends on the maximum urine flow, a value showing variations among individual animals (Column 5, Table IV).

Tables III and IV permit a comparison of preinfusion plasma potassium levels in control and steroid-treated animals (Column 10, Table III and Column 12, Table IV). DCA was found to be most effective in depressing plasma potassium levels in dogs on a high sodium intake.

Finally, a striking feature in all experiments is the high coefficient of correlation for linear regression (see Column 8, Table III and Column 9, Table IV). Also, a similar high correlation coefficient, quite often in excess of 0.99 , was observed in control and steroid-treated animals. Thus, in spite of large variations in the absolute values of the regression coefficients (slopes) under various experimental conditions, there is maintained a high degree of constancy of those factors which affect the relationship between urine flow and osmolal clearance, implying considerable regularity of the underlying physiological process (11).

\section{DISCUSSION}

The most important feature of our observations is that administration of DCA in hydropenic dogs results in a reduced concentrating ability of the kidney. In spite of substantial infusions of exogenous antidiuretic hormone, this effect is exaggerated at higher urine flow rates and thus is frequently associated with the formation of a urine markedly hypotonic to plasma. According to presently held views, the formation of an osmotically concentrated urine is envisaged in the following manner (27-29): Glomerular filtrate is reduced in volume during its passage along the proximal tubule by reabsorption of an isosmotic fluid.

\footnotetext{
${ }^{3}$ In agreement with results obtained by other authors (22), we have observed in some control experiments the excretion of a hypotonic urine during massive osmotic diuresis (urine flows above $15 \mathrm{ml}$. per minute). Therefore, we have arbitrarily limited our observations to lower flow rates.
} 
Therefore, no change in the osmotic pressure of the tubule fluid occurs at this site. Active sodium transport out of the water-impermeable distal part of Henle's loop dilutes the tubular urine and achieves hypertonicity of the medullary interstitial fluid. In the presence of endogenous or exogenous antidiuretic hormone, the distal tubule and collecting duct is relatively water-permeable. Consequently the hypotonicity of the tubular urine is dissipated as water equilibrates with cortical interstitial fluid, resulting in the elaboration of a reduced volume of isosmotic fluid in the second part of the distal convoluted tubule. Finally, the collecting ducts, being permeable to water, permit further equilibration, this time with the hypertonic medullary interstitial fluid, rendering the final urine osmotically more concentrated than plasma.

We believe that the reduced ability of the kidney to concentrate the urine after DCA treatment is due, at least to some extent, to diminished permeability of the distal tubule and the collecting duct to water; thus less water leaves the tubule lumen in response to the osmotic gradient established by solute reabsorption. In particular it is suggested that the frequently observed hypotonicity of the urine represents a failure of the second part of the distal convolute and the collecting duct to concentrate the hypotonic fluid which emerges from Henle's loop. As urine flow increases and less time is available for the dissipation of an osmotic gradient across a membrane less permeable to water, the final urine would, in essence, approach the tonicity of the fluid within the first part of the distal tubule. The reduction of the slope of the regression line of $\mathrm{C}_{\mathrm{osm}}$ on $\mathrm{V}$, almost invariably observed after DCA treatment, is in accord with such an interpretation. Thus, the reduced slopes are consistent with our view that in the presence of diminished water-permeability of the distal tubular epithelium, reabsorption of water, presumed to be a passive process, does not, as usually, proceed from a hyposmotic to an isosmotic level. As urine flow increases at higher rates of solute excretion (increasing mannitol diuresis), back-diffusion of water may progressively lag behind the reabsorption of solutes, thereby preventing the attainment of an osmotic equilibrium between hyposmotic tubular urine and peritubular fluid. Abstraction of only a small amount of solute-free water from an increasingly hypotonic fluid would lead first to a reduction of $\mathrm{T}^{\mathrm{c}}{ }_{\mathrm{H}_{2} \mathrm{O}}$ and, at higher urine flow rates, to a progressive increase in $\mathrm{C}_{\mathrm{H}_{2} \mathrm{O}}$. Only at low urine flow rates would the fluid traversing the distal tubule be rendered isosmotic, since only then sufficient time would be available for the dissipation of the osmotic gradient between tubular urine and cortical interstitial fluid. Indeed, micropuncture studies by Gottschalk, Mylle, Winters and Welt (30) have shown that the osmolality of distal tubule fluid in hydropenic, potassium-depleted rats was similar to that of control animals, in spite of the fact that in the former group the urine was less concentrated. Abstraction of a reduced amount of solute-free water from an isosmotic distal tubular fluid is consistent with our results and those obtained by other authors $(8,30)$ showing that, although diminished, osmolal U/P ratios in excess of unity are regularly observed at low urine flows. According to this interpretation, the decrease in final water abstraction at low urine flows would be attributable to a diminished permeability of the collecting ducts to water.

A second line of evidence in favor of the collecting duct system to be involved in the functional defect of the renal concentrating mechanism is the finding of Oliver and his associates (31) that the collecting ducts are uniformly affected in potassium depleted rats. Their observations of swelling and hyperplasia of the tubular epithelium and intracellular accumulation of granules as well as marked thickening of the basement membrane might be consistent with decreased water permeability of these renal tubular structures.

While the results of our experiments can be explained by decreased permeability of the distal tubules and the collecting duct system to water, a number of alternative or additional possibilities must be considered.

First, sodium reabsorption might be diminished at some critical site within the nephron after DCA and/or potassium depletion. Failure of sodium conservation, either at the level of Henle's loop $(13,14)$ or the collecting ducts $(32)$, could result in diminished hypertonicity of medullary interstitial fluid. As a consequence, diffusion of water out of the terminal part of the nephron due to a diminished osmotic concentration gradient might render the urine less concentrated. ${ }^{4}$

\footnotetext{
4 A number of sodium transport mechanisms are known to be sensitive to lack of potassium (33-36). Since proxi-
} 
Second, sodium reabsorption may be relatively enhanced following DCA administration, increasing free water and rendering the fluid within the distal tubule and collecting duct more hypotonic. Again, particularly at high urine flow rates, water reabsorption might lag sufficiently to permit excretion of hypotonic urine. While in dietary potassium depletion no increase in hypotonicity of the early distal tubule fluid has been found in micropuncture studies (30), such a possibility cannot be ruled out in steroid-treated animals. Also, sodium and chloride retention are known to occur during the development of experimental potassium depletion (4).

Third, although it is very unlikely, changes in filtration rate could have been responsible for the observed alterations in the renal concentrating process. A comparison of mean control filtration rates (Column 11, Table III) with data obtained in DCA-treated animals (Column 13, Table IV) shows that usually there was at most a moderate decrease in filtration rate in the latter group. However, a reduction in glomerular filtration rate of the magnitude observed would tend to increase urine osmolality rather than to decrease it (28, 37). To test whether nephron activity was changed following DCA administration associated with a state of potassium deficiency, glucose $T_{m}$ measurements were done on two animals (Dogs No. 1 and 2) prior to and following steroid treatment. No change was observed in spite of marked and typical alterations in the urinary concentrating ability. Also, glucose titrations showed no difference in splay. Hence, we believe that alterations in filtration rate or of nephron perfusion are excluded as the factor responsible for the difference in the concentrating ability which we observed.

\section{SUMMARY}

1. Administration of DCA ( $1.0 \mathrm{mg}$. per $\mathrm{Kg}$. per day for 6 to 24 days) to dogs on a high sodium chloride intake resulted in reduction of maximum osmotic U/P ratios at low urine flows in the hydropenic state. During mannitol diuresis and vasopressin infusion, the amount of solute-free

mal and distal sodium reabsorption show a number of essential functional differences, it is possible that the latter, involved in the establishment of considerable concentration gradients, is more sensitive to potassium deficiency. water reabsorption $\left(\mathrm{T}^{\mathrm{c}}{ }_{\mathrm{H}_{2} \mathrm{O}}\right)$ was significantly decreased. At urine flow rates above $5 \mathrm{ml}$. per minute, the urine was frequently hypotonic. The slope of osmolal clearance on urine flow was significantly less (mean, 0.777 ) than in control animals (0.994). These changes were vasopressinresistant. Plasma potassium levels were reduced, indicating potassium deficiency. Discontinuation of DCA and administration of potassium chloride supplements showed that the observed alterations were reversible.

2. Hydrocortisone (7.5 mg. per $\mathrm{Kg}$. per day and $10.0 \mathrm{mg}$. per $\mathrm{Kg}$. per day for periods of 6 to 13 days) did not significantly decrease maximum osmolal U/P ratios, $\mathrm{T}^{\mathrm{c}} \mathrm{H}_{2} \mathrm{O}$ or the slope relating $\mathrm{C}_{\text {osm }}$ to $\mathrm{V}$. This steroid was also ineffective in dogs on a high sodium chloride intake to reduce the plasma potassium level.

3 . The data presented have been interpreted to indicate a diminished permeability of the renal epithelium of the distal tubules and collecting ducts to water after DCA and potassium depletion. However, redistribution of solute reabsorption within the nephron has not been excluded.

\section{REFERENCES}

1. Ragan, C., Ferrebee, J. W., Phyfe, P., Atchley, D. W., and Loeb, R. F. Syndrome of polydipsia and polyuria induced in normal animals by desoxycorticosterone acetate. Amer. J. Physiol. 1940, 131, 73.

2. Ferrebee, J. W., Parker, D., Carnes, W. H., Gerity, M. K., Atchley, D. W., and Loeb, R. F. Certain effects of desoxycorticosterone; the development of "diabetes insipidus" and the replacement of muscle potassium by sodium in normal dogs. Amer. J. Physiol. 1941, 135, 230.

3. Dustan, H. P., Corcoran, A. C., and Page, I. H. Renal function in primary aldosteronism. J. clin. Invest. 1956, 35, 1357.

4. Relman, A. S., and Schwartz, W. B. The kidney in potassium depletion. Amer. J. Med. 1958, 24, 764.

5. Stanbury, S. W., Gowenlock, A. H., and Mahler, R. F. Interrelationship of potassium deficiency and renal disease in Aldosterone, A. F. Muller and C. M. O’Connor, Eds. London, Churchill, 1958, p. 155.

6. Smith, S. G., and Lasater, T. E. A diabetes insipiduslike condition produced in dogs by a potassium deficient diet. Proc. Soc. exp. Biol. (N. Y.) 1950, 74, 427.

7. Brokaw, A. Renal hypertrophy and polydipsia in potassium-deficient rats. Amer. J. Physiol. 1953, 172,333 . 
8. Hollander, W., Jr., Winters, R. W., Williams, T. F., Bradley, J., Oliver, J., and Welt, L. G. Defect in the renal tubular reabsorption of water associated with potassium depletion in rats. Amer. J. Physiol. 1957, 189, 557.

9. Milne, M. D., and Muehrke, R. C. Potassium deficiency and the kidney. Brit. med. Bull. 1957, 13, 15.

10. Wesson, L. G., Jr., and Anslow, W. P., Jr. Effect of osmotic and mercurial diuresis on simultaneous water diuresis. Amer. J. Physiol. 1952, 170, 255.

11. Zak, G. A., Brun, C., and Smith, H. W. The mechanism of formation of osmotically concentrated urine during the antidiuretic state. J. clin. Invest. 1954, 33, 1064.

12. Brodsky, W. A., Rapoport, S., and West, C. D. The mechanism of glycosuric diuresis in diabetic man. J. clin. Invest. 1950, 29, 1021.

13. Wirz, H. Der osmotische Druck in den corticalen Tubuli der Rattenniere. Helv. physiol. pharmacol. Acta 1956, 14, 353.

14. Gottschalk, C. W., and Mylle, M. Micropuncture study of osmolality of renal tubular fluid in the hydropenic rat during osmotic diuresis. Fed. Proc. 1958, 17, 58.

15. Epstein, F. H., Kleeman, C. R., Pursel, S., and Hendrikx, A. The effect of feeding protein and urea on the renal concentrating process. J. clin. Invest. 1957, 36, 635.

16. Giebisch, G., MacLeod, M. B., and Pitts, R. F. Effect of adrenal steroids on renal tubular reabsorption of bicarbonate. Amer. J. Physiol. 1955, 183, 377.

17. Howell, D. S., and Davis, J. O. Relationship of sodium retention to potassium excretion by the kidney during administration of desoxycorticosterone acetate to dogs. Amer. J. Physiol. 1954, 179, 359.

18. Relman, A. S., and Schwartz, W. B. The effect of DOCA on electrolyte balance in normal man and its relation to sodium chloride intake. Yale J. Biol. Med. 1952, 24, 540.

19. Page, L. B., and Reem, G. H. Urinary concentrating mechanism in the dog. Amer. J. Physiol. 1952, 171, 572.

20. Peters, J. P., and Van Slyke, D. D. Quantitative Clinical Chemistry. Baltimore, Williams and Wilkins, 1943.

21. Kessler, R. H., Heidenreich, O. P. A., and Pitts, R. F. Evaluation of cell separation hypothesis of autoregulation of renal blood flow and filtration rate. Glucose titrations in normal and anemic dogs. Amer. J. Physiol. 1957, 191, 501.

22. Orloff, J., Wagner, H. N., Jr., and Davidson, D. G. The effect of variations in solute excretion and vasopressin dosage on the excretion of water in the dog. J. clin. Invest. 1958, 37, 458.

23. Mulinos, M. G., Spingarn, C. L., and Lojkin, M. E. Diabetes insipidus-like condition produced by small doses of desoxycorticosterone acetate in dogs. Amer. J. Physiol. 1941, 135, 102.
24. Davis, J. O., and Howell, D. S. Comparative effects of ACTH, cortisone and DCA on renal function, electrolyte excretion and water exchange in normal dogs. Endocrinology 1953, 52, 245.

25. Cooke, R. E., Segar, W. E., Reed, C., Etzwiler, D. D., Vita, M., Brusilow, S., and Darrow, D. C. The role of potassium in the prevention of alkalosis. Amer. J. Med. 1954, 17, 180.

26. Welt, L. G. The influence of disease on the renal excretion of water. Yale J. Biol. Med. 1956, 29, 299.

27. Smith, H. W. The Kidney, Structure and Function in Health and Disease. New York, Oxford University Press, 1951.

28. Berliner, R. W., Levinsky, N. G., Davidson, D. G., and Eden, M. Dilution and concentration of the urine and the action of the antidiuretic hormone. Amer. J. Med. 1958, 24, 730.

29. Wirz, H. The location of antidiuretic action in the mammalian kidney in The Neurohypophysis, Proceedings of the Eighth Symposium of the Colston Research Society, H. Heller, Ed. New York, Academic Press Inc., 1957, p. 157.

30. Gottschalk, C. W., Mylle, M., Winters, R. W., and Welt, L. G. Micropuncture study of the osmolality of renal tubular fluid in potassium-depleted rats (abstract). J. clin. Invest. 1958, 37, 898.

31. Oliver, J., MacDowell, M., Welt, L. G., Holliday, M. A., Hollander, W., Jr., Winters, R. W., Williams, T. F., and Segar, W. E. The renal lesions of electrolyte imbalance. I. The structural alterations in potassium-depleted rats. J. exp. Med. 1957, $106,563$.

32. Hilger, H. H., Kluemper, J. D., and Ullrich, K. J. Mikroanalytische Untersuchungen ueber die Wasser-und Natriumrueckresorption aus den Sammelrohren der Säugetierniere. Pflüg. Arch. ges. Physiol. 1957, 266, 57.

33. Huf, E. G., Doss, N. S., and Wills, J. P. Effects of metabolic inhibitors and drugs on ion transport and oxygen consumption in isolated frog skin. J. gen. Physiol. 1957, 41, 397.

34. Glynn, I. M. Sodium and potassium movements in human red cells. J. Physiol. (Lond.) 1956, 134, 278.

35. Keynes, R. D. The ionic fluxes in frog muscle. Proc. roy. Soc. B 1954, 142, 359.

36. Hodgkin, A. L., and Keynes, R. D. Active transport of cations in giant axons from Sepia and Loligo. J. Physiol. (Lond.) 1955, 128, 28.

37. Levinsky, N. G., Davidson, D. G., and Berliner, R. W. Effects of reduced glomerular filtration on urine concentration in the presence of antidiuretic hormone (abstract). J. clin. Invest. 1958, 37, 910.

38. Boyarsky, S., and Smith, H. W. Renal concentrating operation at low urine flows. J. Urol. (Balt.) 1957, 78, 511. 